\title{
Anatomic Assessment of the Acetabular Fossa for Screw Fixation in Acetabular Fracture
}

\author{
Ye Yeon Won, M.D., Dae Yong Han, M.D.*, Byung Woo Min, M.D. ${ }^{\dagger}$ In Hyuk Chung, M.D. ${ }^{\ddagger}$, \\ and Man Kyung Kim, M.D. \\ Department of Orthopaedic Surgery, Ajou University, School of Medicine, Suwon; Department of Orthopaedic Surgery, \\ National Health Insurance Corporation lisan Hospital*, Goyang; Department of Orthopaedic Surgery, Keimyung University, \\ School of Medicine ${ }^{\dagger}$, Daegu; Department of Gross Anatomy, Yonsei University, College of Medicine ${ }^{\ddagger}$, Seoul, Korea
}

\begin{abstract}
Purpose: To obtain spatial information on the acetabular fossa concerning 'transacetabular screw' insertion through the acetabular fossa parallel to the quadrilateral surface for fixing an acetabular fracture. Materials and Methods: Each hemipelvis harvested from 25 adult fresh frozen cadavers was sectioned into eight segments. This resulted in seven measuring points located along the outer margin of the acetabular fossa. At these points, we measured and compared the vertical thicknesses of cartilage and bone from the quadrilateral surface.

Results: The average thickness of the thinnest portion of the acetabular fossa floor was $3.9 \pm 1.9 \mathrm{~mm}$. The entire thickness of the bone and cartilage measured vertically from the quadrilateral surface at the 7 points ranged from $12.7 \pm 2.1 \mathrm{~mm}$ to $17.8 \pm 3.8 \mathrm{~mm}$. The thinnest safe space of exposed threads of the 'transacetabular screw' inserted through the acetabular fossa was consistently just below the posterior conus of the lunate surface, measuring $4.8 \pm 1.6 \mathrm{~mm}(p<0.05)$. At the other points, it measured 8.3-10.8 $\mathrm{mm}$. Conclusion: We suggest that 'transacetabular screws' can be inserted safely if due consideration is paid to the spatial characteristics of on the acetabular fossa. Screw insertion into the postero-inferior portion of the acetbular fossa should be done carefully.
\end{abstract}

Key Words: Acetabular fracture, Screw fixation, Acetabular fossa

Many authors have reported good results after the anatomical reduction and internal fixation of complex acetabular fractures $^{3-6,10)}$. However, accurate reduction of all articular fracture fragments and firm internal fixation are imperative for if good results are to be obtained, because acetabular fractures are basically articular fractures ${ }^{4,6}$. Often, it is necessary for screws to be inserted through the acetabular fossa parallel to the quadrilateral surface. Usually, this type of screw insertion is performed without a complete view of the acetabular fossa. Thus, it cannot be guaranteed that screw threads are exposed beyond the acetabular fossa and cartilage may be damaged. If screw threads are in contact with the cartilage of the femoral head or acetabulum, the effects will be

Address reprint requests to

Ye Yeon Won, M.D.

Department of Orthopaedic Surgery, Ajou University School of Medicine,

San 5, Woncheon-dong, Yeongtong-gu, Suwon 442-721, Korea

Tel: +82.31-219-5220, Fax: +82.31-219-5229

E-mail: thrtkr@madang.ajou.ac.kr disastrous, resulting in pain and arthritis.

To our knowledge, no spatial information on the acetabular fossa is available with regard to screw fixation for acetabular fractures. The authors conducted this study to obtain such spatial information for safe 'transacetabular screw' insertion through the acetabular fossa parallel to the quadrilateral surface, without damage to joint surfaces.

\section{MATERIALS AND METHODS}

Twenty-five hemipelves (male:female=21:4, Right:left= 11:14) from 25 Korean adult fresh frozen cadavers with no hip joint related disorders were denuded of all soft tissue. No hemipelves with cartilage defects on the lunate surface were included in the current study. Mean age was 55 years (range: 32 to 82). Each hemipelvis was sectioned into eight segments according to the following guidelines using a surgical saw ( $3 \mathrm{M}$ maxi-driver electric ${ }^{\mathrm{TM}}$, $3 \mathrm{M}$ health care, Irvine, CA, USA) (Fig. 1). 


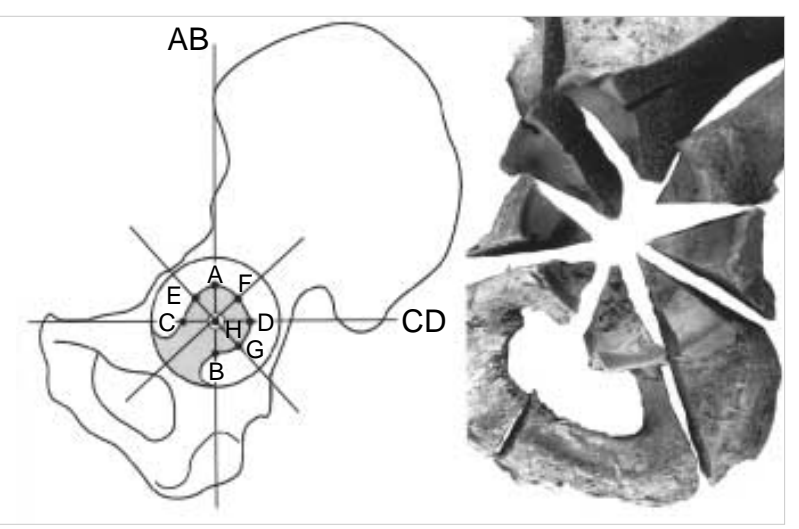

Fig. 1. Left: Illustration showing the hemipelvis sectioning method. Line $A B$ connects the anterior superior iliac spine and the center of the acetabulum $(H)$. Line $C D$ is perpendicular to line $A B$. Line $A B$ and $C D$ divide the acetabulum into four quadrants. $E$, $F$ and $G$ points are on the mid points of the anterosuperior, posterosuperior and posteroinferior quadrants, respectively. Right: Photograph showing a hemipelvis which was sectioned according to the illustration on the left hand side.

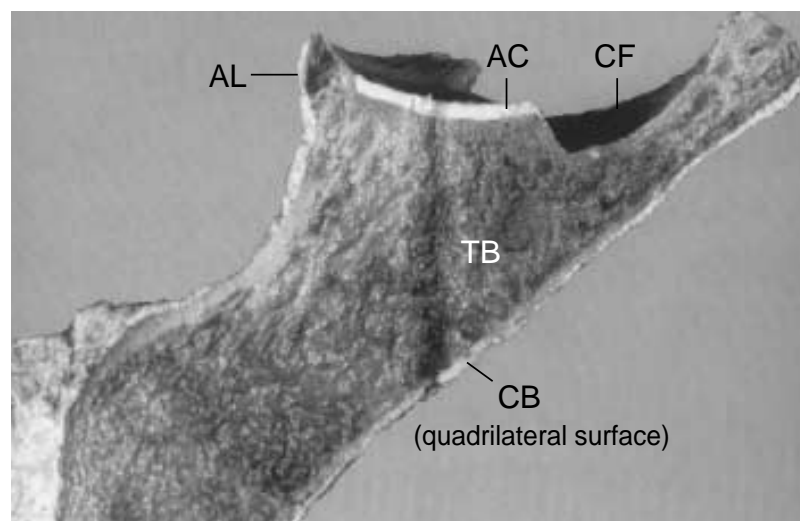

Fig. 2. Photograph showing a side view of one segment of the hemipelvis. AL, acetabular labrum; $\mathrm{AC}$, acetabular cartilage; $\mathrm{CF}$, acetabular fossa; TB, trabecular bone; $\mathrm{CB}$, cortical bone.

(1) A line from the anterior superior iliac spine to the center of the acetabulum was drawn and another line was drawn perpendicular to the first line at the center of the acetabulum. These two lines sectioned the acetabulum into four quadrants.

(2) An additional two lines bisecting the aforementioned four quadrants were drawn through the center of the acetabulum, thus sectioning the acetabulum into eight segments.

This process resulted in seven equidistanced measuring points located along the outer margin of the acetabular fossa. To describe the measured values systematically, the letters A to $\mathrm{H}$ were assigned to the seven points (A-G) and to the center of the acetabulum $(\mathrm{H})$. After washing with pressur-

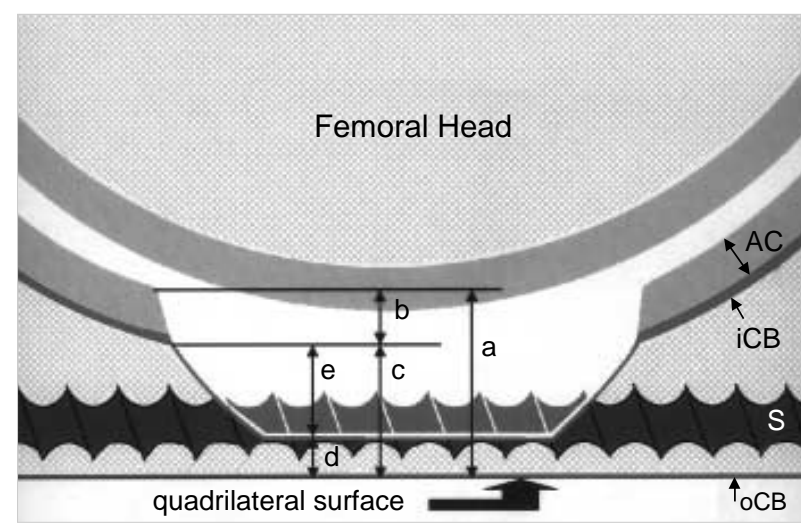

Fig. 3. Illustration showing the method of measurement. Parameter e shows the safe space for a 'transacetabular screw' in acetabular fracture fixation. $\mathrm{AC}$, articular cartilage; iCB, cortical bone on the articular surface (subchondral cortex); OCB, cortical bone on the opposite side of the articular surface; S, screw; $a$, entire thickness measured from the quadrilateral surface to the articular cartilage; $b$, combined thickness of the articular cartilage and subchondral cortex; c, a-b; $d$, thickness of the thinnest portion of the acetabular fossa floor; e, c-d.

ized tap water, the cut surface of each segment was magnified (6-10 times) and observed under a surgical microscope (Zeiss ${ }^{\circledR}$, Germany) (Fig. 2). We then measured the thickness of cartilage and bone along the vertical lines drawn from the individual measuring points to the quadrilateral surface using a digimatic caliper ${ }^{\circledR} 2061$ (Mitutoyo ${ }^{\circledR}$, Japan) to an accuracy of $0.01 \mathrm{~mm}$. To simplify the three-dimensional concept of the acetabular fossa, we assumed that the thinnest portion of the acetabular fossa floor would be located at the center and that the outer margin of the acetabular fossa would have a common shape. We defined "the safe thickness" of the acetabular fossa as the region where the threads of a screw inserted through the acetabular fossa would not damage the joint cartilage. Actually, we calculated the safe thickness (e) of the acetabular fossa using the equation $e=a-b-d$ at each measuring point, where $a, b, d$ and $d$ were defined as follows (Fig. 3):

a: the vertical thickness of all tissue (cartilage and bone) measured from the quadrilateral surface to each point on the inner margin of the lunate surface.

b: the vertical thickness of the articular cartilage and subchondral cortex.

$\mathrm{d}$ : the thickness of the thinnest portion of the acetabular fossa floor.

$\mathrm{d}$ : the mean value of $\mathrm{d}$

We compared the measured values at each point by using 
post-Hoc multiple comparison of one-way ANOVA in SPSS ver. 10.0. Because of the small numbers of subjects in our study, no intergender comparisons could be made.

\section{RESULTS}

The average thickness (d) of the thinnest portion of the acetabular fossa floor was 3.9-1.9 mm (range: 1.2-8.5 mm). The safe thickness of the acetabular fossa was smallest at point $\mathrm{B}$ (posterior inferior portion of the acetabular fossa just above the posterior conus of the lunate surface), which measured $4.8 \pm 1.6 \mathrm{~mm}$. This finding was statistically significant $(\mathrm{p}<$ $0.05)$. At the other points, measurements ranged from 8.3 $\pm 1.7 \mathrm{~mm}$ to $10.8 \pm 2.5 \mathrm{~mm}$ (Fig. 4). Of the seven measuring points, the safe thickness was greater than $10 \mathrm{~mm}$ at points $\mathrm{A}$ (just below the anterior inferior iliac spine), $\mathrm{D}$ (mid-portion of the posterior wall), and $\mathrm{F}$ (superior portion of the posterior wall), measuring $10.3 \mathrm{~mm}, 10.0 \mathrm{~mm}$ and $10.8 \mathrm{~mm}$, respectively. The combined thickness (b) of the cartilage and subchondral cortex was thickest at point $\mathrm{C}$

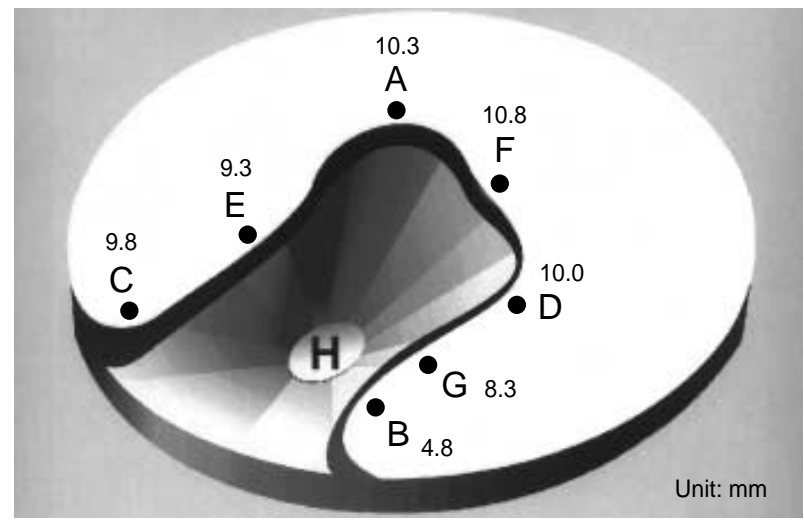

Fig. 4. Illustration showing the mean values of the thickness of the safe space in the left acetabulum. The safe space was thinnest at point $B$. At the other points, the safe space ranged from $8.3 \mathrm{~mm}$ to $10.8 \mathrm{~mm}$.

Table 1. Summary of results (unit=mm)

\begin{tabular}{lccccc}
\hline \multirow{2}{*}{ Measuring points (Mean $\left.\pm{ }^{*} \mathrm{SD}\right)$} & \multicolumn{5}{c}{ Parameters } \\
\cline { 2 - 6 } & $\mathrm{a}$ & $\mathrm{b}$ & $\mathrm{c}$ & ${ }^{\dagger} \mathrm{d}$ & $\mathrm{e}(\mathrm{range})$ \\
\hline $\mathrm{A}$ & $16.0 \pm 3.3$ & $1.8 \pm 0.7$ & $14.2 \pm 3.4$ & $3.9 \pm 1.9$ & $10.3 \pm 2.3(8.8-13.5)$ \\
$\mathrm{B}$ & $12.7 \pm 2.1$ & $4.0 \pm 1.8$ & $8.7 \pm 2.4$ & $3.9 \pm 1.9$ & $4.8 \pm 1.6(3.3-7.1)$ \\
C & $18.3 \pm 2.7$ & $4.6 \pm 1.8$ & $13.7 \pm 3.0$ & $3.9 \pm 1.9$ & $9.8 \pm 2.8(7.1-13.3)$ \\
D & $15.7 \pm 3.2$ & $1.8 \pm 0.8$ & $13.7 \pm 3.3$ & $3.9 \pm 1.9$ & $10.0 \pm 2.5(6.7-13.2)$ \\
E & $15.8 \pm 2.9$ & $2.6 \pm 1.0$ & $13.2 \pm 2.9$ & $3.9 \pm 1.9$ & $9.3 \pm 2.2(6.1-12.1)$ \\
F & $16.4 \pm 3.3$ & $1.7 \pm 0.7$ & $14.7 \pm 3.3$ & $3.9 \pm 1.9$ & $10.8 \pm 2.5(7.2-13.9)$ \\
G & $14.2 \pm 2.4$ & $2.2 \pm 1.0$ & $12.0 \pm 2.5$ & $3.9 \pm 1.9$ & $8.3 \pm 1.7(7.0-11.9)$ \\
\hline
\end{tabular}

*SD, Standard Deviation; ' $\bar{d}$, mean thickness of the thinnest portion of the acetabular fossa floor in twenty-five hemipelves.
$(4.6 \pm 1.8 \mathrm{~mm})$ and thinnest at point $\mathrm{F}(1.7 \pm 0.7 \mathrm{~mm})$. The entire thickness (a) of bone and cartilage, which was vertically measured from the quadrilateral surface to each measuring point, ranged from $12.7 \pm 2.1 \mathrm{~mm}$ (point B) to 18.3 $\pm 2.7 \mathrm{~mm}$ (point $\mathrm{C}$ ) (Table 1). However, these findings were not statistically different $(\mathrm{p}>0.05)$.

\section{DISCUSSION}

It is widely accepted that open reduction and internal fixation of a displaced acetabular fracture can result in a satisfactory clinical outcome $\mathrm{e}^{3-6,10)}$. In addition, anatomic reduction and firm internal fixation, although technically demanding, is required because acetabular fractures are basically articular fractures ${ }^{4,6}$. Inadequate fixation, however, can invite postoperative reduction loss and result in revisional surgery ${ }^{3,8,9)}$. During this procedure, it is often necessary for screws to be inserted through the acetabular fossa parallel to the quadrilateral surface, but sometimes inadvertently a screw will damage the articular cartilage. Occasionally a screw perforates and traverses the acetabular fossa but dose not impede rotation of the femoral head because the screw is distanced from it, as long as the articular cartilage is intact. To avoid damaging the articular cartilage, when long $3.5 \mathrm{~mm}$ screws are inserted into the posterior column from the pelvic brim, or into the anterior column from a retroacetabular surface, they must run parallel to the quadrilateral surface of the ischium $^{4)}$. Some reports have raised concerns about the techniques to used confirm intra-articular screw penetration ${ }^{1,2)}$. Ebraheim et al. reported that a combination of a cross-table lateral view of the hip and a Judet iliac view are more informative than AP or Judet obturator views for demonstrating the absence or presence of a screw in the hip joint ${ }^{2}$. Brown et al. used postoperative $\mathrm{CT}$ scans in conjunction with intraoperative images to confirm accurate screw placement dur- 
ing operations on complex, displaced acetabular fractures, and reported that in no case was screw or pin removal required $^{1)}$. This technique has proven useful for the accurate placement of screws and pins around the acetabulum. However, their technique required intra-operative image guidance and postoperative CT scans, which are both expensive and time-consuming. Regardless of the techniques used to confirm screw intra-articular penetration, there is a basic demand for spatial information on the acetabular fossa. We conducted this study to provide guidelines for safe transacetabular screw fixation for screws inserted into the acetabular fossa along the quadrilateral surface in Korean adult pelves.

Anterior screw placement, posterior screw placement, and posterior column lag screw placement from an ilioinguinal approach are required to ensure a contoured pelvic reconstruction plate in cases of complex acetabular fracture. Accurate reduction of all fracture fragments is imperative since the articular surface is not directly visualized using this approach. As long as screws are placed parallel to the quadrilateral surface, perforation into the acetabular fossa may not endanger the cartilage of the femoral head. For this particular situation, surgeons should consider three possible scenarios with respect to the degree of thread exposure: 1) all threads are completely embedded into the floor of the acetabular fossa; 2) threads are partially exposed; 3) threads are completely exposed $^{4)}$. Unfortunately, it is not easy to differentiate one scenario from another in the operating field. In addition, in the last two scenarios, there is a possibility that the exposed screw threads might damage the articular cartilage of the femoral head. According to the current study, the entire thickness (a) of bone and cartilage, measured vertically from the quadrilateral surface to each measuring point, ranged from $12.7 \pm 2.1 \mathrm{~mm}$ (point B) to $18.3 \pm 2.7 \mathrm{~mm}$ (point C). We presume from these findings that long $4.5 \mathrm{~mm}$ or 3.5 $\mathrm{mm}$ screws might be inserted safely into any point if the surgeon in able to insert these screws parallel to the quadrilateral surface according to the first or second of the three scenarios. However, surgeons should consider the fact that the average thickness (d) of the thinnest portion of the acetabular fossa floor is $3.9 \pm 1.9 \mathrm{~mm}$ (range: $1.2-8.5 \mathrm{~mm}$ ), because the direction of a screw can change during insertion. Should scenario three (completely exposed threads) occurs, the surgeon cannot guarantee safety, especially when using larger screws ( $4.5 \mathrm{~mm}$ or $6.5 \mathrm{~mm}$ screws) at point $\mathrm{B}$, because the safe region of the acetabular fossa is consistently thinner (4.8 $\pm 1.6 \mathrm{~mm})$ at this point $(\mathrm{p}<0.05)$. Point $\mathrm{B}$ is located at the posterior inferior portion of the acetabular fossa, just below the posterior conus of the lunate surface.

All of the parameters measured in this study could be considered to ensure safe screw fixation (Table 1). For example, at point $\mathrm{B}$, the safe thickness (e) was thinnest $(4.8 \pm 1.6 \mathrm{~mm})$ and the tissue thickness (c), which excluded the thickness of cartilage and subchondral cortex, was also thinnest $(8.7 \pm$ $2.4 \mathrm{~mm}$ ). The combined thickness (b) of cartilage and subchondral cortex, was although statistically not significant, was thickest at point $\mathrm{C}(4.6 \pm 1.8 \mathrm{~mm})$ and thinnest at point $\mathrm{F}(1.7 \pm 0.7 \mathrm{~mm})$. We measured this parameter because screw placement is safe if the screw is inside the subchondral cortex and not inside the articular cartilage. Surgeons should been in mind that whole tissue thickness (a) is greatest (18.3 $\pm 2.7 \mathrm{~mm}$ ) at point $C$ (just below the anterior conus of the lunate surface) and thinnest $(12.7 \pm 2.1 \mathrm{~mm}$ ) at point $\mathrm{B}$ (just below the posterior conus of the lunate surface) (Fig. 4).

In terms of the author's results (Table 1), the combined thickness (b) of cartilage and subchondral cortex was thinnest at point $\mathrm{F}(1.7 \pm 0.7 \mathrm{~mm})$. This point is the weight bearing portion of the acetabulum, and is considered to have thicker cartilage than other regions. This disparity also implies that the author's specimens may have shown early stage osteoarthritis.

Noble reported that the posterior inferior portion of the acetabulum is composed of relatively thick bone for acetabular cup screw fixation ${ }^{7}$. However, our results seem to contradict Noble's, because different measuring points were used, Noble measured the middle of the articular surface, whereas we measured along the outer margin of the acetabular fossa.

Our study has some weak points, we presumed initially that the thinnest portion of the acetabular fossa floor is located at the center of the acetabular fossa. However, while performing this study, we found that the thinnest portion is not always located at the center of the acetabular fossa. Thus, we measured the thinnest portion of the acetabular fossa floor before the cutting procedure and calculated the mean and standard deviation $(3.9 \pm 1.9 \mathrm{~mm})$. We then used this mean thickness (d) to calculating the safe thickness.

Summarizing, we suggest that the safe thickness for 'transacetabular screw' placement is consistently smaller at the 
posterior conus of the lunate surface than in other regions of the acetabular fossa, and that a transacetabular screw can be inserted safely by considering the spatial characteristics of the acetabular fossa.

\section{REFERENCES}

\section{Brown GA, Willis MC, Firoozbakhsh K, Barmada A, Tess-} man CL and Montgomery A: Computed tomography image guided surgery in complex acetabular fractures. Clin Orthop, 370: 219-226, 2000.

2. Ebraheim NA, Savolaine ER, Hoeflinger MJ and Jackson WT: Radiological diagnosis of screw penetration of the hip joint in acetabular fracture reconstruction. J Orthopaedic Trauma, 3: 196-201, 1989.

3. Heeg M, Klasen HJ and Visser JD: Operative treatment for acetabular fractures. J Bone Joint Surg, 72-B: 383-386, 1990.

4. Letournel E and Judet R: Fractures of the acetabulum. Second ed. New York, etc: Springer-Verlag, 410-411, 436-437, 1993.

5. Liebergall M, Mosheiff R, Low J, Goldvirt M, Matan Y and Segal D: Acetabular fractures-clinical outcome of surgical treatment. Clin Orthop, 366: 205-216, 1999.

6. Matta JM and Merritt PO: Displaced acetabular fractures. Clin Orthop, 230: 83-97, 1988.

7. Noble PC: Contribution of basic and applied sciences to hip replacement in the older patient. Instructional Course Lectures, 38: $381-$ 392, 1994.

8. Pennal GF, Davidson J, Garside $\mathrm{H}$ and Plewes J: Results of treatment of acetabular fractures. Clin Orthop, 151: 115-123, 1980.

9. Routt ML Jr and Swiontkowski MF: Operative treatment of complex acetabular fractures. Combined anterior and posterior exposures during the same procedure. J Bone Joint Surg, 72-A: 897-904, 1990.

10. Tile M: Fractures of the pelvis and acetabulum. Second ed. Baltimore, etc: Williams \& Wilkins, 321-354, 1995.

\title{
비구 골절에 대한 나사못 고정시 비구와의 안전 공간에 대한 해부학적 연구
}

\author{
원예연 · 한대용 ${ }^{\star}$. 민병우 · 정인혁 ${ }^{\ddagger}$. 김만경 \\ 아주대학교 의과대학 정형외과학교실, 국민의료보험관리공단 일산병원 정형외과학교실*, 계명대학교 의과대학 정형외과학교실 ${ }^{\dagger}$, \\ 연세대학교 의과대학 해부학교실 ${ }^{\ddagger}$
}

목 적: 비구골절에서 비구의 사각형면에 평행하면서 비구와를 관통하는 나사못을 삽입하는 경우에 알아야 할 비구와의 공 간적 정보를 알아보고자 하였다.

대상 및 방법: 성인 사체의 반쪽 골반 25 쪽을 8 토막으로 절단하여 절단선들이 비구와의 가장자리를 따라 만나는 7 개의 측 정점을 얻었다. 사각형면으로부터 이들 점들까지의 수직선상에서 연골 및 뼈의 두께를 측정하고 비교하였다.

결 과: 비구와 바닥의 두께가 가장 얇은 부위의 평균 두께는 $3.9 \pm 1.9 \mathrm{~mm}$ 이었다. 사각형면으로부터 수직으로 측정한 뼈 및 연골의 총 두께의 평균은 $12.7 \pm 2.1 \mathrm{~mm}$ 에서 $17.8 \pm 3.8 \mathrm{~mm}$ 의 범위에 있었다. 비구와의 안전 공간이 제일 작은 부위는 후하방 지역으로 평균 4.8 $\pm 1.6 \mathrm{~mm}$ ( $\mathrm{p}<0.05$ )이었으며 다른 부위에서는 평균 8.3-10.0 mm이었다.

결 론: 본 연구의 형태학적 계측자료에 의하면 비구와의 안전 공간이 제일 작은 부위는 후하방 구역이었으므로 이 구역을 피하여 나사못을 삽입하는 것이 안전하다고 사료된다.

색인 단어: 비구 골절, 나사못 고정, 비구와 